\title{
PENDEKATAN HOLISTIK TRANSPORTASI BERBASIS APLIKASI DALAM KERANGKA HUKUM PERLINDUNGAN KONSUMEN*
}

\author{
Agus Suwandono** \\ Departemen Hukum Ekonomi, Fakultas Hukum, Universitas Padjadjaran \\ Jl. Dipati Ukur No. 35 Bandung, Jawa Barat, 40123
}

\begin{abstract}
Regulations of transportation based applications still get a rejection, while the government as the regulator may concern to provide protection for public transport providers and consumers. This research method is the juridical normative with descriptive analytical specifications. The results showed that the regulations of the transportation-based application should pay attention to the interests of consumers, businessperson and the government. In addition, there are no regulation abaut ojek online causes the absence of legal certainty to the existence of ojek online. Legal protection of the consumer transportation based applications in some aspects have fulfilled this aspect of consumer protection, by remaining attentive to the rights of other consumers.
\end{abstract}

Keywords: transportations, based application, consumers, holistic.

\section{Intisari}

Pengaturan transportasi berbasis aplikasi masih saja mendapatkan penolakan, sementara pemerintah selaku regulator berkepentingan untuk memberikan perlindungan bagi angkutan konvensional dan konsumen. Penelitian ini bersifat yuridis normatif dengan spesifikasi deskriftif analitis. Hasil penelitian menunjukkan bahwa pengaturan transportasi berbasis aplikasi harus memperhatikan kepentingan konsumen, pelaku usaha dan pemerintah. Selain itu, tidak diaturnya ojek online menyebabkan tidak adanya kepastian hukum terhadap keberadaan ojek online. Perlindungan hukum terhadap konsumen transportasi berbasis aplikasi dalam beberapa aspek telah memenuhi aspek perlindungan konsumen, dengan tetap memperhatikan hakhak konsumen yang lainnya.

Kata kunci: transportasi, berbasis aplikasi, konsumen, holistik.

\section{Pokok Muatan}

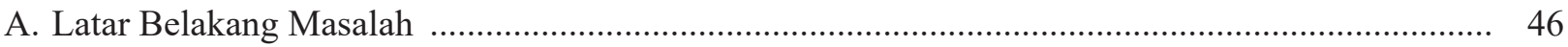

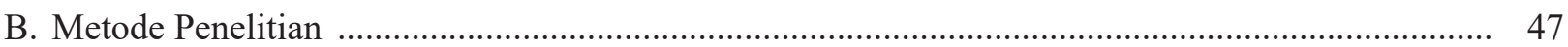

C. Hasil Penelitian dan Pembahasan ...................................................................................... 47

1. Pengaturan Transportasi Berbasis Aplikasi dalam Kerangka Hukum Perlindungan Konsumen 47

2. Perlindungan Hukum Terhadap Konsumen Transportasi Berbasis Aplikasi dalam Perspektif Perlindungan Konsumen ............................................................................. 53

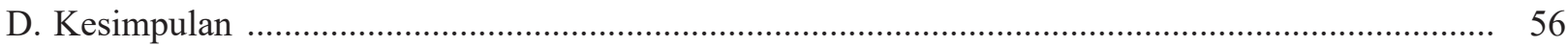

Hasil Penelitian yang didanai secara mandiri pada tahun 2017.

Alamat korespondensi: agus.suwandono@unpad.ac.id. 


\section{A. Latar Belakang Masalah}

Transportasi berbasis aplikasi telah menjadi salah satu moda transportasi baru di masyarakat. Moda transportasi yang awalnya didominasi oleh transportasi konvensional saat ini perlahan dan pasti mulai bergeser ke moda transportasi berbasis teknologi informasi. Pergeseran ini terjadi karena perkembangan teknologi, pelayanan, kemudahan dan tarif yang ditawarkan oleh para penyelenggara transportasi berbasis aplikasi yang menarik bagi para calon konsumennya.

Keberadaan transportasi berbasis aplikasi sampai saat masih menimbulkan pro dan kontra di masyarakat. Keberadaan transportasi berbasis aplikasi, di satu sisi merupakan salah satu alternatif moda transportasi yang memberikan kemudahan askes bagi para konsumen. Akan tetapi di sisi yang lain, keberadaannya juga mendapatkan penolakan dari penyelenggara moda transportasi konvensional seperti ojek konvensional, angkutan kota, dan taksi, yang seringkali menimbulkan gesekan dan bentrokan antara para pengemudi transportasi konvensional dengan transportasi berbasis aplikasi. Hal ini terjadi karena keberadaan transportasi berbasis aplikasi ini dianggap telah mengurangi dan mematikan penghasilan para pelaku transportasi konvensional yang telah ada sebelumnya. ${ }^{1}$

Kementerian Perhubungan selaku regulator di bidang transportasi pada awalnya juga menolak keberadaan transportasi berbasis aplikasi khususnya kendaraan bermotor roda dua (ojek online). Kementerian Perhubungan melarang beroperasi ojek online karena beralasan kendaraan bermotor dalam hal ini ojek online tidak berizin, tidak memenuhi ketentuan hukum, serta mengabaikan faktor keamanan. ${ }^{2}$

Kementerian Perhubungan menyikapi keberadaan transportasi berbasis aplikasi kemudian mengeluarkan beberapa peraturan. Peraturan tersebut tertuang dalam Peraturan Menteri Perhubungan Nomor 32 Tahun 2016 tentang Penyelenggaraan Angkutan Orang dengan Kendaraan Bermotor Umum tidak dalam Trayek (Permenhub No. 32 Tahun 2016), yang kemudian dicabut dengan Peraturan Menteri Perhubungan Nomor 26 Tahun 2017 tentang Penyelenggaran Angkutan Orang dengan Kendaraan Bermotor Umum tidak dalam Trayek (Permenhub No. 26 Tahun 2017). Selanjutnya dalam perkembangan dinamika transportasi berbasis aplikasi serta adanya Putusan Mahkamah Agung Nomor 37 P/HUM/2017 tentang Permohonan Hak Uji Materiil Terhadap Peraturan Menteri Perhubungan No. 26 Tahun 2017 tentang Penyelenggaraan Angkutan Orang dengan Kendaraan Bermotor Umum tidak dalam Trayek, Kementerian Perhubungan akhirnya mencabut Permenhub No. 26 Tahun 2017 dan menggantinya dengan Peraturan Menteri Perhubungan Nomor 108 Tahun 2017 tentang Penyelenggaraan Angkutan Orang dengan Kendaraan Bermotor Umum tidak dalam Trayek (Permenhub No. 108 Tahun 2017), yang berlaku efektif pada 1 Februari 2018.

Transportasi berbasis aplikasi selain memberikan alternatif moda transportasi yang menawarkan kemudahan serta tarif yang terjangkau, ternyata dalam praktiknya masih memunculkan permasalahan. Permasalahan transportasi berbasis aplikasi ini antara lain berkaitan dengan aspek keamanan dan keselamatan konsumen, seperti terjadinya perampokan yang dilakukan pengemudi taksi online kepada konsumen di Bandung Jawa Barat. ${ }^{3}$ Selain itu juga masih banyak keluhan terkait tarif yang sangat mahal pada jam-jam sibuk (rush hour), yang bisa lebih mahal daripada taksi konvensioal. ${ }^{4}$

Pengguna transportasi berbasis aplikasi pada

Mochamad Solehudin, "Diancam Sopir Angkot, Aher Tunggu Arahan Pusat Soal Taksi Online", https://news.detik.com/berita-jawabarat/d-3676465/diancam-sopir-angkot-aher-tunggu-arahan-pusat-soal-taksi-online, diakses 11 November 2017.

BBC Indonesia, "Pelarangan ojek online: Presiden panggil Menhub", http://www.bbc.com/indonesia/berita_indonesia/2015/12/151218_ indonesia_presidenmenhub, diakses 11 November 2017.

Joko Pambudi, "Pengemudi Rampok Penumpang, Polisi Akan Panggil Manajemen Taksi Online", http://www.pikiran-rakyat.com/bandungraya/2018/01/19/pengemudi-rampok-penumpang-polisi-akan-panggil-manajemen-taksi-online-418193, diakses 19 Januari 2018.

Harian Rakyat Merdeka, "YLKI Dibanjiri Keluhan Kinerja Taksi Online", http://ekbis.rmol.co/read/2017/08/03/301482/YLKI-DibanjiriKeluhan-Kinerja-Taksi-Online-, diakses 26 Desember 2017. 
dasarnya merupakan konsumen. Perlindungan konsumen di Indonesia telah diatur dalam Undang-Undang Nomor 8 Tahun 1999 tentang Perlindungan Konsumen (UUPK). Pasal 2 UUPK telah menentukan bahwa dalam penyelenggaran perlindungan konsumen berasaskan manfaat, keadilan, keseimbangan, keamanan dan keselamatan konsumen, serta kepastian hukum. Selain itu, Pasal 4 UUPK juga telah menentukan hak-hak konsumen antara lain hak untuk untuk mendapatkan kenyamanan, keamanan, dan keselamatan dalam mengkonsumsi barang dan/atau jasa serta hal untuk memilih barang dan/atau jasa serta mendapatkan barang dan/atau jasa tersebut sesuai dengan nilai tukar dan kondisi serta jaminan yang dijanjikan.

Fenomena keberadaan transportasi berbasis aplikasi dalam kerangka perlindungan konsumen tidak hanya berkaitan dengan kepentingan konsumen, tetapi juga berkaitan dengan kepentingan pelaku usaha dan pemerintah. Pengaturannya tidak semata hanya didasarkan salah satu pihak tetapi harus memberikan manfaat, keadilan, keamanan, dan kepastian hukum bagi para pihak. Sehingga pengaturan transportasi berbasis aplikasi seharusnya dikaji menggunakan paradigma holistik yakni dengan memandang keseluruhan lebih besar daripada jumlah bagian-bagian. ${ }^{5}$ Selain itu, hukum sangat sulit untuk dilepaskan dari basis sosial, sehingga terjadi interaksi disiplin dan proses saling memasuki. ${ }^{6}$ Hukum tidak bisa dikotakkotakan, melainkan dengan menyatukan kembali hukum dengan realitas masyarakat, sehingga akan mengembalikan keutuhan hukum itu sendiri. ${ }^{7}$ Berdasarkan alasan tersebut penulis tertarik untuk mengkaji permasalahan transportasi berbasis aplikasi ini dengan menggunakan pendekatan holistik dalam kerangka hukum perlindungan. Rumusan masalah dalam penelitian ini yakni bagaimanakah pengaturan transportasi berbasis aplikasi dalam kerangka hukum perlindungan konsumen, serta bagaimanakah perlindungan hukum terhadap konsumen transportasi berbasis aplikasi dalam perspektif perlindungan konsumen.

\section{B. Metode Penelitian}

Metode penelitian yang digunakan dalam penelitian ini merupakan penelitian yuridis normatif, yang meliputi penelitian inventarisasi hukum positif, penelitian terhadap asas-asas hukum dan penelitian hukum in concreto, penelitian sistematik hukum, penelitian sejarah hukum dan perbandingan hukum. ${ }^{8}$ Data sekunder dalam penelitian hukum normatif ini berupa bahan-bahan hukum primer, bahan hukum sekunder dan bahan hukum tersier. ${ }^{9}$

Spesifikasi penelitian ini bersifat deskriptif analitis, yaitu membuat pancaindraan secara sistematis mengenai fakta-fakta ${ }^{10}$ termasuk di dalamnya menggambarkan peraturan-peraturan yang berlaku. ${ }^{11}$ Metode analisis data yang digunakan merupakan normatif kualitatif, yakni penelitian yang bertitik tolak dari peraturan perundang-undangan yang ada sebagai norma hukum positif serta ditunjang oleh hasil pengumpulan data sekunder lainnya. Pengambilan kesimpulan dilaksanakan dengan metode deduktif.

\section{Hasil Penelitian dan Pembahasan \\ 1. Pengaturan Transportasi Berbasis Aplikasi dalam Kerangka Hukum Perlindungan Konsumen}

Hukum Perlindungan konsumen adalah keseluruhan asas-asas dan kaidah-kaidah yang

\footnotetext{
Sudjito, 2014, Ilmu Hukum Holistik : Studi Untuk Memahami Kompleksitas dan Pengaturan Pengelolaan Irigasi, Gadjah Mada University Press, Yogyakarta, hlm. 75.

FX. Adji Samekto, "Menggugat Relasi Filasat Positivisme dengan Ajaran Hukum Doktrinal”, Jurnal Dinamika Hukum, Vol. 12, No. 1, Januari, 2012, hlm. 84.

Theresia Anita Christiani, "Studi Hukum Berdasarkan Perkembangan Paradigma Pemikiran Hukum Menuju Metode Holistik", Jurnal Hukum Pro Justitia, Vol. 26, No. 4, Oktober, 2008, hlm. 357.

Ronny Hanitijo Soemitro, 1990, Metodelogi Penelitian Hukum dan Jurimetri, Ghalia Indonesia, Jakarta, hlm. 9-10.

Soerjono Soekanto, et al, 2006, Penelitian Hukum Normatif suatu Tinjauan Singkat, Rajawali, Jakarta, hlm. 13-14.

Ronny Hanitijo Soemitro, op.cit. hlm. 22.

Sumadi, 1988, Metode Penelitian, Rajawali, Jakarta, hlm. 19.
} 
mengatur dan melindungi konsumen dalam hubungan dan masalah penyediaan dan penggunaan produk (barang dan/atau jasa) konsumen antara penyedia dan penggunanya, dalam kehidupan bermasyarakat. $^{12}$ Asas-asas dan kaidah-kaidah hukum perlindungan pada dasarnya terdapat dalam berbagai peraturan perundang-undangan yang juga mengatur dan melindungi konsumen.

Perlindungan konsumen secara khusus telah diatur dalam UUPK, yang merupakan payung hukum pelaksanaan perlindungan konsumen di Indonesia. Keberadaan UUPK dalam sistem hukum perlindungan konsumen yakni mengintegrasikan berbagai ketentuan peraturan perundang-undangan yang mengatur dan melindungi konsumen baik yang ada sebelum maupun sesudah berlakunya UUPK. ${ }^{13}$

Peraturan perundang-undangan selain UUPK yang mengatur dan melindungi konsumen terdapat dalam berbagai bidang tidak terkecuali bidang transportasi. Salah satu peraturan perundangundangan di bidang transportasi yang tengah menjadi polemik yakni Permenhub No. 108 Tahun 2017 yang mengatur transportasi berbasis aplikasi.

Pemberlakuan Permenhub No. 108 Tahun 2017 yang diharapkan dapat mengakomodir kepentingan semua pihak tampaknya belum dapat terwujud. Aksi unjuk rasa penolakan pemberlakuan Permenhub No. 108 Tahun 2017 masih saja dilakukan para pengemudi transportasi berbasis aplikasi. Sedangkan Kementerian Perhubungan selaku regulator pun tidak bergeming dan tetap memberlakukan peraturan tersebut. Beberapa point krusial dalam Permenhub No. 108 Tahun 2018 juga masih menimbulkan penolakan dari beberapa pihak yang pada akhirnya masuk kembali ke pengadilan melalui proses uji materiil di Mahkamah Agung untuk yang ke-2 (dua) kalinya.

Berdasarkan Putusan Mahkamah Agung No. 15 P/HUM/2018 mengenai Perkara Permohonan
Keberatatan Hak Uji Materiil terhadap beberapa Pasal dalam Permenhub No. 108 Tahun 2018 tentang Penyelenggaraan Angkutan Orang dengan Kendaraan Bermotor Umum tidak dalam Trayek (Putusan MA No. 15 P/ HUM/2018), Mahkamah Agung memerintah kepada Menteri Perhubungan untuk mencabut beberapa pasal Permenhub No. 108 Tahun 2018. Mahkamah Agung berpendapat bahwa pasal-pasal yang dimuat dalam Permenhub No. 108 Tahun 2018 merupakan pemuatan materi ulang muatan norma yang telah dibatalkan oleh Putusan Nomor 37 P/ HUM/2017, tanggal 20 Juni 2017, dan/atau bertentangan dengan peraturan perundangundangan yang lebih tinggi yaitu Pasal 4 dan Pasal 5 Undang-Undang Nomor 20 Tahun 2008 tentang Usaha Mikro, Kecil, dan Menengah, dan karenanya tidak sah dan tidak berlaku umum. ${ }^{14}$

Pengaturan transportasi berbasis aplikasi dalam Permenhub No. 108 Tahun 2017 pada beberapa poin masih menimbulkan perdebatan. Beberapa poin krusial yang masih menjadi perdebatan tersebut yakni sebagai berikut.

Pertama, Permenhub No. 108 Tahun 2017 hanya mengatur angkutan orang dengan kendaraan bermotor umum yakni angkutan orang yang dilayani dengan mobil penumpang umum atau mobil bus umum. ${ }^{15}$ Pengaturan transportasi berbasis aplikasi dari awal mulai dari Permenhub No. 32 Tahun 2016, Permenhub No. 26 Tahun 2017, sampai dengan Permenhub No. 108 Tahun 2017 memang hanya mengatur transportasi berbasis aplikasi yang menggunakan kendaraan roda empat. Kementerian Perhubungan tidak mengakui keberadaan kendaraan roda dua untuk digunakan sebagai anggkutan orang, dengan tidak mengaturnya dalam semua peraturan menteri perhubungan yang diterbitkan. Hal ini tentunya tidak sesuai dengan kenyataannya bahwa transportasi berbasis aplikasi terdiri dari transportasi berbasis aplikasi yang menggunakan

\footnotetext{
Az. Nasution, 2011, Hukum Perlindungan Konsumen : Suatu Pengantar, Diadit Media, Jakarta, hlm. 37.

Penjelasan Umum Undang-Undang Nomor 8 Tahun 1999 tentang Perlindungan Konsumen (Lembaran Negara Republik Indonesia Tahun 1999 Nomor 42, Tambahan Lembaran Negara Republik Indonesia Nomor 3821).

4 Pertimbangan Hukum Putusan Mahkamah Agung Nomor 15 P/HUM/2018 perihal Peninjauan Kembali Daniel Lukas Rorong, dkk Vs Menteri Perhubungan RI, 31 Mei 2018.

5 Pasal 1 angka (3) Peraturan Menteri Perhubungan Nomor 108 Tahun 2017 tentang Penyelenggaraan Angkutan Orang dengan Kendaraan Bermotor Umum tidak dalam Trayek (Berita Negara Republik Indonesia Tahun 2017 Nomor 1474).
} 
kendaraan bermotor roda empat (taksi online) dan transportasi berbasis aplikasi yang menggunakan kendaraan bermotor roda dua (ojek online).

Pengaturan transportasi berbasis aplikasi dalam Permenhub No. 108 Tahun 2017 yang hanya mengatur mengenai taksi online cukup beralasan. Hal ini didasarkan pada ketentuan Undang-Undang Nomor 22 Tahun 2009 tentang Lalu Lintas dan Angkutan Jalan (UU No. 22 Tahun 2009) yang membedakan kriteria kendaraan bermotor umum dengan sepeda motor. Kendaraan bermotor umum merupakan kendaraan yang digunakan untuk angkutan barang dan/atau orang dengan dipungut bayaran, ${ }^{16}$ sedangkan sepeda motor adalah kendaraan bermotor beroda dua dengan atau tanpa rumah-rumah dan dengan atau tanpa kereta samping atau kendaraan bermotor beroda tiga tanpa rumahrumah. ${ }^{17}$ Berdasarkan UU No. 22 Tahun 2009 maka sepeda motor tidak termasuk dalam kreteria sebagai kendaraan bermotor umum karena sepeda motor bukanlah kendaaraan bermotor umum yang ditujukan untuk angkutan barang dan/atau orang yang dipungut biaya.

Mencermati tidak diaturnya ojek online sebagai salah satu transportasi berbasis aplikasi oleh pemerintah (Kementerian Perhubungan) dengan membiarkannya tanpa pengaturan tentunya bukanlah suatu jawaban yang tepat atas keberadaan ojek online. Kebijakan pemerintah dengan membiarkan keberadaan ojek online tanpa adanya payung hukum dirasakan tidak memberikan kepastian hukum bagi pengemudi ojek online, perusahan penyedia aplikasi, dan konsumen karena alasan sepeda motor tidak masuk kriteria sebagai kendaraan bermotor umum sebagaimana dimaksud dalam UU No. 22 Tahun 2009 maupun PP No. 74 Tahun 2014.

Fenomena keberadaan ojek online sebagai salah satu bagian transportasi berbasis aplikasi tidak dapat dihindari keberadaannya. Ojek online merupakan salah satu bentuk kreatifitas ekonomi yang memanfaatkan kecanggihan teknologi informasi. Perkembangan teknologi serta tuntutan kebutuhan masyarakat memerlukan terobosanterobosan yang seringkali berbenturan dengan aturan yang kaku. Sedangkan pada hakikatnya hukum tumbuh dan berkembang (walaupun pelan) mengikuti perkembangan zaman. Selain itu, tidak dapat disangkal bahwa keberadaan ojek online juga turut menggerakkan dan berkembangkan sektor usaha kecil menengah. Seperti diketahui bahwa ojek online selain menyediakan layanan jasa trasnsportasi juga menyediakan layanan-layanan lainnya seperti jasa kurir (pengantar) barang, pembelian produk untuk keperluan pribadi maupun keperluan rumah tangga.

Pengaturan transportasi berbasis aplikasi tidak hanya melihat pada adanya dikotomi antara konvensional dan online semata, tetapi lebih pada irisan yang ada di dalamnya dengan karakteristiknya masing-masing. Pengaturan taksi online dan ojek online pada dasarnya merupakan 2 (dua) hal yang berbeda. Taksi online lebih menitikberatkan pada layanan penyelenggaraan transportasi, sedangkan layanan ojek online tidak hanya menitikberatkan kepada layanan penyelenggaraan transportasi semata tetapi juga memberikan layanan-layanan lainnya dengan berbasis aplikasi.

Penyelenggaraan transportasi berbasis aplikasi juga harus mempertimbangkan kepastian hukum. Kepastian hukum dalam penyelenggaran perlindungan konsumen merupakan salah satu asas dalam UUPK. Kepastian hukum ini sesungguhnya dimaksudkan agar baik pelaku usaha maupun konsumen menaati hukum dan memperoleh keadilan dalam penyelenggaraan perlindungan konsumen, serta negara menjamin kepastian hukum. ${ }^{18}$ Melihat keberadaan ojek online di masyarakat yang

16 Pasal 1 angka (10) Undang-Undang Nomor 22 Tahun 2009 tentang Lalu Lintas dan Angkutan Jalan (Lembaran Negara Republik Indonesia Tahun 2009 Nomor 96, Tambahan Lembaran Negara Republik Indonesia Nomor 5025).

17 Pasal 1 angka (20) Undang-Undang Nomor 22 Tahun 2009 tentang Lalu Lintas dan Angkutan Jalan (Lembaran Negara Republik Indonesia Tahun 2009 Nomor 96, Tambahan Lembaran Negara Republik Indonesia Nomor 5025).

18 Penjelasan Pasal 2 angka (5) Undang-Undang Nomor 8 Tahun 1999 tentang Perlindungan Konsumen (Lembaran Negara Republik Indonesia Tahun 1999 Nomor 42, Tambahan Lembaran Negara Republik Indonesia Nomor 3821). 
dibiarkan tanpa adanya payung hukum terhadap ojek online menyebabkan keberadaannya menjadi liar. Tidak ada aturan yang dapat dipedomani bagi perusahaan aplikasi, pengemudi ojek online dan konsumen dapat menyebabkan ketidaktertiban dalam penyelenggaraan layanan ojek online, karena alasan bertentangan dengan regulasi di bidang transportasi. Hal ini tentunya tidak sesuai dengan salah satu tujuan hukum yakni mewujudkan ketertiban. Hukum seharusnya hadir untuk mewujudkan ketertiban dan kepastian hukum.

Kedua, Pasal 64 ayat (1) Permenhub No. 108 Tahun 2017 menentukan bahwa perusahaan angkutan umum yang menggunakan aplikasi berbasis teknologi informasi, wajib mengikuti ketentuan di bidang pengusahaan angkutan umum antara lain memiliki izin penyelenggaraan angkutan orang dengan kendaraan bermotor umum tidak dalam trayek ${ }^{19}$ dan berbentuk badan hukum. ${ }^{20}$

Pengaturan Permenhub No. 108 Tahun 2017 yang mengatur pengemudi taksi online untuk tunduk pada ketentuan mengenai perusahaan angkutan umum, sepertinya ingin menyamakan aturan bagi pengemudi taksi online untuk memenuhi persyaratan seperti perusahaan angkutan umum. Hal ini memang dirasakan dapat memberikan keadilan bagi pelaku usaha transportasi umum dengan pengemudi taksi online. Bagi transportasi konvensional untuk dapat menyelenggarakan kegiatan angkutan jalan harus memenuhi persyaratan sebagai perusahaan angkutan umum, sedangkan bagi pengemudi taksi online tidak ada kewajiban untuk itu. Hal ini tentunya menyebabkan posisi start yang tidak seimbang bagi transportasi konvensional karena adanya keharusan memenuhi syarat sebagai perusahaan angkutan umum. Hal ini tentunya dapat berpengaruh pada cost yang lebih besar yang harus dikeluarkan oleh perusahaan angkutan umum yang dapat mempengaruhi besarnya tarif layanan penyelenggaran transportasi konvensional, karena harus menutup biaya operasional yang besar.

Keadilan menjadi bagian yang tidak terpisahkan dari tujuan hukum itu sendiri. ${ }^{21}$ Hukum dibuat untuk menciptakan ketertiban melalui peraturan yang adil, yakni pengaturan kepentingankepentingan yang saling bertentangan dengan seimbang sehingga setiap orang memperoleh sebanyak mungkin apa yang menjadi bagiannya. ${ }^{22}$ Keadilan merupakan salah satu asas yang terdapat dalam UUPK yang menentukan agar partisipasi seluruh rakyat dapat diwujudkan secara maksimal dan memberikan kesempatan kepada konsumen dan pelaku usaha untuk memperoleh haknya dan melaksanakan kewajibannya secara adil. Pentingnya keadilan bagi penyelenggaran transportasi umum dan transportasi berbasis aplikasi memang sudah seharusnya diwujudkan, hanya saja jangan kemudian justru dapat mematikan salah satu pihak. Hal ini sesuai dengan Penjelasan Umum UUPK yang meyatakan bahwa piranti hukum yang melindungi konsumen tidak dimaksudkan untuk mematikan usaha para pelaku usaha, tetapi justru sebaliknya perlindungan konsumen dapat mendorong iklim berusaha yang sehat yang mendorong lahirnya perusahaan yang tangguh dalam menghadapi persaingan melalui penyediaan barang dan/atau jasa yang berkualitas.

Pada umumnya keadilan menuntut agar semua orang diperlakukan sama. Keadilan merupakan suatu nilai yang mewujudkan keseimbangan antara bagian-bagian dalam masyarakat, antara tujuan pribadi dan tujuan bersama. ${ }^{23}$ Adil bagi perusahaan angkutan umum belum tentu dapat adil bagi penyelenggaran transportasi berbasis

19 Pasal 36 ayat (1) Peraturan Menteri Perhubungan Nomor 108 Tahun 2017 tentang Penyelenggaraan Angkutan Orang dengan Kendaraan Bermotor Umum tidak dalam Trayek (Berita Negara Republik Indonesia Tahun 2017 Nomor 1474).

20 Pasal 37 Peraturan Menteri Perhubungan Nomor 108 Tahun 2017 tentang Penyelenggaraan Angkutan Orang dengan Kendaraan Bermotor Umum tidak dalam Trayek (Berita Negara Republik Indonesia Tahun 2017 Nomor 1474).

21 Inge Dwisvimiar, "Keadilan dalam Perspektif Filsafat Ilmu Hukum”, Jurnal Dinamika Hukum, Vol 11, No. 3, September, 2011, hlm. 524.

22 Herri Swantoro, et. all, "Permohonan Upaya Hukum Peninjauan Kembali Kedua Kali Berbasis Keadilan dan Kepastian Hukum", Mimbar Hukum, Vol. 29, No. 2, Juni, 2017, hlm, 198.

23 Bahder Johan Nasution, “Kajian Filosofis Tentang Konsep Keadilan dari Pemikiran Klasik Sampai Pemikiran Modern”, Jurnal Yustisia, Vol. 3, No. 2, Mei - Agustus, 2014, hlm. 125. 
aplikasi, begitu sebaliknya, untuk mewujudkan keadilan harus dilihat secara proporsional yakni apakah antara perusahaan angkutan umum konvensioanl dengan transportasi berbasis aplikasi itu sama, sehingga harus diperlakukan sama untuk memberikan keadilan, atau diantara kedua moda transportasi tersebut berbeda sehingga tidak bisa diperlakukan sama.

Pengaturan mengenai taksi online dalam Permenhub No. 108 Tahun 2017 yang mewajibkan untuk tunduk pada aturan transportasi pada umumnya tidak sepenuhnya tepat. Transportasi berbasis aplikasi tidak bisa disamakan dengan transportasi umum karena taksi online memiliki karakteristik tersendiri yang berbeda dari transportasi konvensional pada umumnya. Sekmen pasar taksi online merupakan konsumen individual yang menginginkan kenyamanan, kemudahan akses serta tarif yang terjangkau. Transportasi berbasis aplikasi dipandang sebagai transportasi yang berorientasi pada transportasi privat, sehingga pengaturan tidak dapat disamakan dengan pengaturan penyelenggaraan transportasi umum.

Ketiga, Pasal 65 Permenhub No. 108 Tahun 2017 menentukan perusahaan aplikasi di bidang transportasi darat dilarang bertindak sebagai penyelenggara angkutan umum, antara lain memberikan layanan akses aplikasi kepada perorangan, perekrutan pengemudi, penetapan tarif, selain itu perusahaan aplikasi di bidang transportasi darat wajib berbadan hukum Indonesia. ${ }^{24}$ Pengaturan Permenhub No. 108 Tahun 2017 memisahkan fungsi antara perusahaan angkutan umum dengan perusahaan aplikasi di bidang transportasi. Perusahaan aplikasi di bidang transportasi tidak dapat sekaligus bertindak sebagai perusahaan angkutan umum dengan merekrut sendiri pengemudi taksi online. Berdasarkan Permenhub No. 108 Tahun 2017 para pengemudi taksi online harus berkedudukan sebagai perusahaan angkutan umum, sehingga harus memenuhi persyaratan layaknya sebagai perusahaan anggkutan umum, yang tentunya akan memberatkan bagi para pengemudi taksi online. Hal ini tentunya tidak tidak sejalan dengan semangat pegembangan ekonomi kreatif yang mencoba mengurangi dan menghilangkan hambatan-hambatan dalam kegiatan ekonomi.

Keempat, Pasal 44 huruf (d) Permenhub No. 108 Tahun 2017 menentukan bahwa perusahaan angkutan umum mempekerjakan pengemudi yang telah memiliki Surat Izin Mengemudi (SIM) Umum sesuai dengan golongannya. Berdasarkan Pasal 44 huruf (d) Permenhub No. 108 Tahun 2017 ini menentukan bahwa pengemudi transportasi berbasis aplikasi merupakan karyawan dari perusahaan angkutan umum. Selain itu, jika dikaitkan dengan ketentuan Pasal 39 ayat (2) Permenhub No. 108 Tahun 2017 maka pengemudi perseorangan dapat terhimpun dalam perusahaan angkutan umum yang berbadan hukum koperasi yang telah memiliki izin penyelenggaraan angkutan umum. Pengaturan seperti ini tampaknya dapat lebih menata, mengatur, serta mengendalikan jumlah pengemudi taksi online, hanya saja hal ini dapat menyebabkan fleksibilitas pengemudi taksi online menjadi kurang, hal ini tentunya berbeda dengan karakteristik dari pengemudi taksi online yang memberikan keleluasan bagi para pengemudi taksi online untuk menjalankan pekerjaannya. Keberadaan perusahaan dan pengemudi transportasi berbasis aplikasi ini merupakan suatu tuntutan inovasi dan merupakan suatu bentuk pengembangan ekonomi kreatif berbasis teknologi informasi yang perlu dikembangkan dalam rangka pemenuhan hak untuk mendapatkan pekerjaan dan penghidupan yang layak.

Kelima, Pasal 28 ayat (1) Permenhub No. 108 Tahun 2017 menentukan penetapan tarif angkutan sewa khusus dilakukan berdasarkan kesepakatan antara pengguna jasa dan penyedia jasa transportasi melalui aplikasi teknologi informasi dengan berpedoman pada tarif batas atas dan tarif batas

24 Pasal 66 Peraturan Menteri Perhubungan Nomor 108 Tahun 2017 tentang Penyelenggaraan Angkutan Orang dengan Kendaraan Bermotor Umum tidak dalam Trayek (Berita Negara Republik Indonesia Tahun 2017 Nomor 1474). 
bawah. Permasalahan tarif transportasi berbasis aplikasi inilah yang menyebabkan permasalahan dengan transportasi konvensional. Perusahaan aplikasi seperti Gojek, Grab dan Uber selama ini memang menentukan tarif layanan transportasinya berdasarkan nilai keekonomian cost perusahaan mereka, yang bukan cost sebagai perusahaan angkutan umum. Tarif yang ditetapkan oleh perusahaan aplikasi di bawah standar tarif angkutan umum yang notabene ditetapkan oleh pemerintah. Hal inilah yang kemudian menyebabkan perang tarif yang tidak seimbang antara penyelenggara angkutan umum dengan transportasi berbasis aplikasi.

Persyaratan dalam Permenhub No. 108 Tahun 2017 bagi taksi online dalam perspektif pelaku usaha angkutan umum konvensional dan pemerintah selaku regulator sangat wajar dalam rangka pemenuhuan aspek keadilan. Pemerintah harus memberikan keadilan bagi perusahaan angkutan umum konvesional mengingat cost yang telah dikeluarkan dalam rangka penyelenggaraan angkutan umum tersebut. Biaya operasional yang dikeluarkan oleh perusahaan angkutan umum menyebabkan tingginya tarif transportasi konvensional. Hal inilah yang menyebabkan transportasi konvensional tidak mampu bersaing dengan taksi online yang menawarkan tarif yang lebih murah.

Permasalahan tarif transportasi berbasis aplikasi agar kompetitif dengan transportasi umum, perlu adanya penentuan tarif batas bawah dan batas atas berdasarkan kesepakatan stakeholder. Adanya penentuan tarif diharapkan dapat membuat kompetisi antara transportasi berbasis aplikasi dengan transportasi konvensional seimbang serta dapat menghindari kesenjangan dan konflik dan membuat tarif trasnsportasi berbasis aplikasi dan konvensional menjadi kompetitif.

Kebijakan tarif ini tentu dapat menimbulkan kenaikan tarif dalam transportasi berbasis aplikasi yang akan berpengaruh kepada konsumen dan pelaku usaha transportasi berbasis aplikasi. Bagi konsumen, kenaikan tarif layananan diharapkan dapat memberikan dampak dengan peningkatan kualitas layanan. Bagi pengemudi transportasi berbasis aplikasi juga dapat meningkatkan pendapatan, serta bagi perusahaan aplikasi dapat memberikan kontribusi lebih bagi penerimaan kas negara melalui pembayaran pajak.

Keberadaan transportasi berbasis aplikasi baik taksi online maupun ojek online sebagai salah satu alternatif moda transportasi tidak bisa dihindarkan ditengah perkembangan teknologi informasi. Harus diakui bahwa keberadaannya telah memberikan kemudahan akses masyarakat untuk mendapatkan moda transportasi yang nyaman serta tarif yang terjangkau, ditengah kualitas layanan angkutan umum yang belum memadai. Kebijakan yang seharusnya diterapkan adalah memberikan payung hukum bagi keberadaan transportasi berbasis aplikasi secara holistik baik bagi taksi online maupun ojek online dan bukan justru secara parsial. Tidak adanya pengaturan yang mengatur mengenai ojek online dan terkesan membiarkannya tanpa adanya pengaturan dapat dianggap sebagai kebijakan cuci tangan akan persoalan transportasi berbasis aplikasi dan ketidakberdayaan pemerintah menyusun regulasi. Kementerian Perhubungan sebagai regulator sebaiknya dapat mengatur keberadaraan transportasi berbasis aplikasi secara seimbang dengan tetap memperhatikan kepentingan konsumen, pelaku usaha, serta pemerintah sendiri, dengan mengingat karakteristik dari transportasi berbasis aplikasi.

Keberadaan ojek online yang dianggap bertentangan dengan UU No. 22 Tahun 2009 dan PP No. 74 Tahun 2014 tidak berarti bahwa pengaturannya harus dipaksakan disamakan dengan peraturan yang sudah ada, atau bahkan terkesan dibiarkan tanpa ada pengaturannya. Keberadaan transportasi berbasis aplikasi dikaitkan dengan ketatnya regulasi dibidang transportasi dan tuntutan perlindungan bagi konsumen sebaiknya tidak menghambat inovasi di bidang transportasi, melainkan justru diharapkan dapat menggerakan sektor-sektor ekonomi dan mendorong inovasi dan ekonomi kreatif. Tidak dapat dipungkiri bahwa 
keberadaan transportasi berbasis aplikasi dengan berbagai layanan yang ditawarkan telah memberikan manfaat bagi konsumen, pelaku usaha serta pengemudi transportasi berbasis aplikasi, sehingga justru harus dipayungi dengan aturan hukum yang dapat mengakomodir kepentigan konsumen, pelaku usaha dan pemerintah sesuai dengan filosofi dari sistem perlindungan konsumen.

Keberadaan transportasi berbasis aplikasi baik taksi online maupun ojek online harus diakui telah membawa pergeseran dan perubahan di bidang jasa transportasi. Kehadirannya merupakan suatu tuntutan untuk memenuhi kebutuhan masyarakat di bidang transportasi. Hukum sebagai fungsi perlindungan diharapkan dapat melindungi kepentingan manusia, bukan justru menghambat kepentingan manusia. Sesuai dengan sifatnya, kaidah hukum akan berubah mengikuti perkembangan masyarakat, terpengaruh waktu dan tempat (historisch bestimmt), ${ }^{25}$ untuk mewujudkan ketertiban masyarakat. ${ }^{26}$

Perkembangan dan kebutuhan masyarakat akan transportasi yang nyaman, mudah dan tarif yang terjangkau tidak selamanya harus dimaknai sebagai kebutuhan akan transportasi yang bersifat umum atau angkutan umum. Konsumen juga memiliki pilihan untuk menggunakan moda transportasi yang nyaman dan mudah yang ditujukan bagi konsumen individu (privat). Berdasarkan alasan tersebut transportasi berbasis aplikasi dapat dianggap sebagai transportasi tersendiri yang bersifat privat, sehingga bukan sebagai angkutan umum. Solusi yang dapat ditempuh yakni dengan merevisi ketentuan dalam UU No. 22 Tahun 2009 berkaitan dengan kategori dan jenis angkutan. Revisi ini diperlukan guna mewujudkan ketertiban dalam penyelenggaraan angkutan jalan, dengan mempertimbangkan perkembangan teknologi dan masyarakat dengan tetap mempertimbangan hak dan kewajiban konsumen dan pelaku usaha, serta kepentingan pemerintah sebagai regulator.

Pengaturan transportasi dengan berbagai karekteristiknya, bukanlah semata-mata domain Kementerian Perhubungan semata. Persoalan transportasi khususnya ojek online erat kaitannya dengan layanan-layanan penyediaan produk barang dan jasa. Hal ini berkaitan dengan hubungan pelaku usaha dan konsumen domain Kementerian Perdagangan yang didalamnya juga menaungi permasalahan niaga dan perlindungan konsumen. Pengaturan transportasi berbasis aplikasi harus melibatkan Kementerian Perdagangan. Selain itu, Pengaturan transportasi berbasis aplikasi juga erat kaitannya dengan penggunaan teknologi informasi, dimana hal ini merupakan domain dari Kementerian Komunikasi dan Informasi. Selayaknya juga pengaturan transportasi berbasis aplikasi juga melibatkan Kementerian Komunikasi dan Informasi.

\section{Perlindungan Hukum Terhadap} Konsumen Transportasi Berbasis Aplikasi dalam Perspektif Perlindungan Konsumen

Perlindungan konsumen adalah segala upaya yang menjamin adanya kepastian hukum untuk memberikan perlindungan kepada konsumen. ${ }^{27}$ Perlindungan hukum kepada konsumen pada dasarnya merupakan pemenuhan atas hak-hak konsumen yang seharusnya diberikan kepada konsumen, ${ }^{28}$ sehingga perlindungan konsumen sesungguhnya identik dengan perlindungan yang diberikan hukum terhadap hak-hak konsumen. ${ }^{29}$ Konsumen akan terlindungi apabila hak-haknya sebagai konsumen terpenuhi.

Hak-hak konsumen diatur dalam Pasal 4 UUPK, yang berkaitan dengan produk barang dan/ atau jasa. Salah satu hak konsumen yang berkaitan dengan jasa antara lain yakni hak konsumen di bidang jasa transportasi. Salah satu permasalahan

\footnotetext{
Sudikno Mertokusumo, 2006, Penemuan Hukum : Sebuah Pengantar, Liberty, Yogyakarta, hlm. 9.

Ibid., hlm. 11.

Pasal 1 ayat (1) Undang-Undang Nomor 8 Tahun 1999 tentang Perlindungan Konsumen (Lembaran Negara Republik Indonesia Tahun 1999 Nomor 42, Tambahan Lembaran Negara Republik Indonesia Nomor 3821).

Janus Sidabalok, 2006, Hukum Perlidungan konsumen di Indonesia, Citra Aditya Bakti, Bandung, hlm. 10

Shidarta, 2004, Hukum Perlindungan Konsumen Indonesia, Grasindo, Jakarta, hlm. 19.
} 
transportasi yakni transportasi berbasis aplikasi. Untuk mengetahui perlindungan konsumen terkait transportasi berbasis aplikasi dalam perspektif perlindungan konsumen diuraikan di bawah ini.

Pertama, Pasal 4 angka (1) UUPK menentukan hak konsumen atas kenyamanan, keamanan, dan keselamatan dalam mengkonsumsi barang dan/atau jasa. Kenyamanan konsumen jasa transportasi berbasis aplikasi diwujudkan adanya suatu kondisi perasaan seseorang yang merasa nyaman, senang, tenang, serta tidak ada gangguan. Kenyamanan ini lebih kepada penilaian respon dari individu, sehingga ukurannya bersifat subyektif.

Penilaian akan transpotrasi umum seperti bus dan angkot saat ini bisa dikatakan belum dapat memenuhi harapan konsumen. ${ }^{30}$ Banyak faktor yang mempengaruhi persepsi tersebut antara lain berkaitan kebersihan, kuota jumlah penumpang, pedagang asongan dan pengamen membuat konsumen tidak nyaman. Artinya penilaian kenyamanan ini akan sangat tergantung pada penilian konsumen yang berkaitan dengan kondisi dan lingkungan dalam moda transportasi.

Transportasi berbasis aplikasi menawarkan konsep baru transportasi privat yang ditujukan bagi konsumen individual. Taksi online seperti Go-Car, Uber, Grab menawarkan kenyamanan bagi konsumennya layaknya seperti mengendarai kendaraan pribadi. Taksi online menyasar konsumen individu, sehingga aspek kenyamanan konsumen menjadi yang utama. Seperti taksi online yang menawarkan kenyamanan bagi konsumen, yang terjadi pada ojek online tidak demikian. Secara aspek kenyamanan, ojek online memang berbeda dengan taksi online. Ojek online belum bisa memenuhi aspek kenyamanan seperti taksi online.

Keamanan diartikan sebagai bebas dari bahaya. ${ }^{31}$ Keamanan lalu lintas dan angkutan jalan adalah suatu keadaan terbebasnya setiap orang, barang, dan/atau kendaraan dari gangguan perbuatan melawan hukum, dan/atau rasa takut dalam berlalu lintas. ${ }^{32}$ Aspek keamanan transportasi berbasis aplikasi berarti bahwa alat transportasi tersebut aman atau bebas dari bahaya apabila dipergunakan. Umumnya baik kendaraan roda dua atau roda empat yang dipasarkan telah memenuhi aspek keamanan sesuai dengan peruntukannya. Akan tetapi untuk kendaraan yang diperuntukan bagi angkutan umum untuk mengetahui apakah memenuhi spesifikasi teknis kendaraan bermotor umum, dibutuhkan uji KIR secara berkala. Uji KIR dilaksanakan untuk mengetahui kelayakan secara teknis kendaraan tersebut aman atau tidak untuk dipergunakan, sebagaiman diatur dalam Permenhub No. 108 Tahun 2017. Hal ini memang sudah selayaknya dilaksanakan bagi taksi online untuk dapat menyelenggarakan angkutan umum. Akan tetapi, untuk ojek online yang tidak ada pengaturannya, maka untuk meningkatkan keamanaan perlu dilakukan pemeriksaan sepeda motor secara berkala. Kewajiban pemeriksaan berkala ini bisa diatur oleh perusahaan aplikasi. Pengemudi ojek online diwajibkan untuk memeriksa dan melaporkan hasil pemeriksaan kelayakan sepeda motor, sebagai dasar pertimbangan keberlanjutan kerjasama kemitraan antara pengemudi dengan perusahaan aplikasi.

Keselamatan dalam lalu lintas dan angkutan jalan adalah suatu keadaan terhindarnya setiap orang dari risiko kecelakaan selama berlalu lintas yang disebabkan oleh manusia, kendaraan, jalan, dan/atau lingkungan. ${ }^{33}$ Keselamatan konsumen transportasi berbasis aplikasi dimaksudkan terhindar dari bahaya, malapetaka, serta kejahatan yang terjadi saat menggunakan jasa transportasi berbasis aplikasi.

Keselamatan dalam transportasi berbasis

30 YLKI, "Pelarangan ojek online: YLKI minta angkutan umum 'diperbaiki”” https://www.bbc.com/indonesia/berita_indonesia/2015/12/151218_ indonesia ylki larangangojekdll, diakses 18 November 2018

Pengembang KBBI Daring, "Kamus Besar Bahasa Indonesia”, https://kbbi.kemdikbud.go.id/entri/aman.

32 Pasal 1 angka (30) Undang-Undang Nomor 22 Tahun 2009 tentang Lalu Lintas dan Angkutan Jalan (Lembaran Negara Republik Indonesia Tahun 2009 Nomor 96, Tambahan Lembaran Negara Republik Indonesia Nomor 5025).

33 Pasal 1 angka (31) Undang-Undang Nomor 22 Tahun 2009 tentang Lalu Lintas dan Angkutan Jalan (Lembaran Negara Republik Indonesia Tahun 2009 Nomor 96, Tambahan Lembaran Negara Republik Indonesia Nomor 5025). 
aplikasi dapat terjadi dari faktor pengemudi maupun dari pihak luar. Dari faktor pengemudi, penyelenggara transportasi berbasis aplikasi harus menentukan persyaratan dan kriteria rekrutmen yang ketat bagi pengemudi transportasi berbasis aplikasi. Dengan aplikasi, kejahatan yang terjadi, yang dilakukan pengemudi maupun pihak luar, sebenarnya dapat diketahui dari status perjalanan yang terekam di data server yang dimiliki oleh perusahaan aplikasi. Apabila terjadi kejahatan yang dilakukan oleh pengemudi transportasi berbasis aplikasi maka dapat diketahui siapa yang harus bertanggung jawab. Akan tetapi, pihak perusahaan transportasi berbasis aplikasi harus dapat memastikan bahwa setiap layanan transportasi berbasis aplikasi benar-benar dipergunakan oleh pengemudi yang sesuai dengan data di perusahaan aplikasi. Selain itu, untuk lebih memberikan jaminan keselamatan bagi konsumen taksi online maupun ojek online, konsumen dapat dicover dengan asuransi. Adapun premi asuransi dapat dimasukan ke dalam komponen tarif layanan transportasi berbasis aplikasi.

Kedua, Pasal 4 angka (2) UUPK menentukan konsumenn memiliki hak untuk memilih barang dan/atau jasa serta mendapatkan barang dan/atau jasa tersebut sesuai dengan nilai tukar dan kondisi serta jaminan yang dijanjikan. Konsumen yang mengunakan jasa transportasi memiliki hak untuk memilih dan menentukan jasa transportasi yang akan dipilih. Bagi konsumen, pilihan untuk memilih transportasi berbasis aplikasi atau transportasi konvensional didasarkan pertimbangan antara lain terkait kenyamanan, keamanan, keselamatan, kemudahan, serta tarif yang terjangkau.

Keberadaan transportasi berbasis aplikasi merupakan alternatif moda transportasi selain transportasi konvensional yang sudah ada. Konsumen akan memilih transportasi yang menawarkan kenyamanan, kemudahan maupun tarif yang terjangkau. Angkutan umum yang tidak sesuai dengan harapan konsumen secara alamiah akan ditinggalkan oleh konsumen. Hal ini dapat memberikan masukan kepada pemerintah maupun penyelenggara angkutan umum untuk meningkatkan kualitas layananan serta menyediakan moda transportasi umum yang nyaman, aman, mudah serta tarif yang terjangkau. Hal ini sesuai dengan Pasal 14 ayat (1) PP No. 74 Tahun 2014 yang menentukan kewajiban penyedia angkutan umum untuk menyelenggarakan angkutan umum memenuhi kebutuhan angkutan orang dan/ atau barang yang selamat, aman, nyaman, dan terjangkau.

Munculnya transportasi berbasis aplikasi ditengah angkutan umum memberikan alternatif pilihan moda transportasi, yang pada akhirnya konsumen memiliki banyak pilihan untuk memilih moda transportasi yang nyaman, aman, mudah, terjangkau serta tarif yang terjangkau. Kondisi demikian akan semakin melindungi konsumen untuk memilih moda transportasi sesuai dengan keinginan konsumen.

Ketiga, Pasal 4 angka (3) UUPK menentukan konsumen memiliki hak atas informasi yang benar, jelas, dan jujur mengenai kondisi dan jaminan barang dan/atau jasa. Hak informasi diperlukan agar konsumen tidak mempunyai gambaran yang keliru atas jasa yang dipakainya. ${ }^{34}$ Transportasi berbasis aplikasi yang berbasis aplikasi di smartphone memiliki beberapa fitur yang dapat memberikan informasi mengenai layanan transportasi berbasis aplikasi. Konsumen dapat mengakses informasi jelas mengenai jenis layanan, tarif layanan serta kondisi perjalanan. Informasi jenis layanan tranportasi berbasis aplikasi, disertai dengan tarif yang pasti berdasarkan jarak yang akan ditempuh. Selain itu, konsumen juga dapat memantau layanan digunakan melalui aplikasi di smartphone.

Keempat, Pasal 4 angka (4) UUPK menentukan konsumen memiliki hak untuk didengar pendapat dan keluhannya atas barang dan/atau jasa yang digunakan. Hak ini memberikan ruang bagi konsumen untuk menyampaikan pendapat dan

34 Shidarta, Op.cit., hlm. 23-24. 
keluhan pada saat menggunakan jasa transportasi berbasis aplikasi. Saran dan keluhan dari konsumen kepada penyelenggara transportasi akan sangat bermanfaat bagi perbaikan layanan yang diberikan oleh penyelenggara transportasi berbasis aplikasi.

Keberadaan transportasi berbasis aplikasi dalam beberapa aspek pemenuhan hak-hak konsumen telah memenuhi aspek perlindungan konsumen. Hanya saja dari aspek kemanan dan keselamatan konsumen perlu mendapatkan perhatian baik dari pelaku usaha maupun pemerintah selaku regulator. Penyelenggara aplikasi transportasi berbasis aplikasi diharapkan mampu meningkatkan keamanan serta keselamatan konsumen, sedangkan pemerintah diharapkan dapat memberikan regulasi yang dapat mengakomodir perlindungan bagi konsumen serta kepentingan pelaku usaha baik penyelenggara transportasi berbasis aplikasi dan pengemudinya serta perusahaan transportasi konvensional.

Perlindungan konsumen dalam transportasi berbasis aplikasi tidak dimaksudkan untuk mematikan pelaku usaha atau pengemudi transportasi berbasis aplikasi. Bahwa tujuan dari perlindungan konsumen yakni untuk meningkatkan kualitas barang dan/atau jasa yang menjamin kelangsungan usaha dengan tetap memperhatikan aspek kenyamanan, kemanan, dan keselamatan konsumen. Dengan adanya tuntutan perlindungan konsumen ini diharapkan dapat meningkatkan layanan transportasi berbasis aplikasi yang lebih baik yang dapat memenuhi hak-hak konsumen.

\section{Kesimpulan}

Pengaturan transportasi berbasis aplikasi dikategorikan menjadi 2 (dua) kategori yakni pengaturan taksi online dan ojek online. Pembeda pengaturan ini dikarenakan kedua jenis transportasi berbasis aplikasi tersebut berbeda yang memiliki karakteristik masing-masing dengan jenis layanan yang disediakan. Pengaturan taksi online secara umum dapat dikategorikan sebagai angkutan umum, namun demikian keberadaannya tidak harus dikategorikan sebagai angkutan umum. Taksi online digolongkan sebagai kendaraan angkutan privat yang berbeda angkutan umum pada umumnya, sehingga pengaturannya berbeda dengan peraturan yang mengatur penyelenggaraan angkutan umum. Ojek online tidak dapat dikategorikan sebagai angkutan umum karena tidak memenuhi kriteria sebagai kendaraan umum. Tidak diaturnya ojek online karena terbenturnya regulasi di bidang transportasi dengan membiarkannya tanpa payung hukum menyebabkan ketidakpastian hukum.

Pilihan untuk membiarkan keberadaan ojek online dengan tidak mengaturnya bukan jawaban yang tepat. Hukum harus hadir untuk mewujudkan kepastian hukum, ketertiban, dan kemanfaatan bagi masyarakat. Pengaturan transportasi berbasis aplikasi harus dapat mengatur secara keseluruhan keberadaan tranportasi berbasis aplikasi baik taksi online dan ojek online, di mana harus mengakomodir kepentingan konsumen, pelaku usaha baik penyelenggara dan pengemudi tansportasi berbasis aplikasi, pelaku usaha transportasi konvensional, serta pemerintah. Solusi yang dapat ditempuh sambil menunggu revisi UU No. 22 Tahun 2009 terkait dengan kriteria dari angkutan umum, dengan mengingat semangat mengembangkan ekonomi kreatif berbasis teknologi informasi serta menggeliatkan sektor usaha kecil menengah maka ojek online dapat digunakan sebagai sarana angkut tetapi tidak dikategorikan sebagai angkutan umum. Hal ini mengingat bahwa layanan transportasi ojek online hanya merupakan salah satu jenis layanan ojek online selain layanan-layanan lainnya.

Perlindungan hukum terhadap konsumen transportasi berbasis aplikasi dalam beberapa aspek telah memenuhi perlindungan terhadap hak-hak konsumen, khususnya taksi online. Namun demikian, untuk ojek online, dalam aspek kenyamanan, keamanan, dan keselamatan terkait dengan penyelenggaran tranportasi berbasis aplikasi belum terpenuhi. Penyelenggara transportasi berbasis aplikasi dalam rangka meningkatkan perlindungan konsumen terutama terkait dengan aspek kenyamanan, keamanan, dan keselamatan harus menetapkan standar dan 
kriteria aspek kendaraan bermotor serta pengemudi transportasi berbasis aplikasi. Perusahaan aplikasi dapat memperketat serta selektif dalam merekrut para calon pengemudi sesuai dengan persyaratan yang telah ditentukan perusahaan, serta melakukan pengawasan dan pemantauan kepatuhan para pengemudi serta aspek teknis kendaraan sesuai dengan ketentuan yang ditentukan oleh perusahaan.

\section{DAFTAR PUSTAKA}

\section{A. Buku}

Mertokusumo, Sudikno, 2006, Penemuan Hukum : Sebuah Pengantar, Liberty, Yogyakarta.

Nasution, Az., 2011, Hukum Perlindungan Konsumen : Suatu Pengantar, Diadit Media, Jakarta.

Shidarta, 2004, Hukum Perlindungan Konsumen Indonesia, Grasindo, Jakarta.

Sidabalok, Janus, 2006, Hukum Perlidungan konsumen di Indonesia, Citra Aditya Bakti, Bandung.

Soekanto, Soerjono, et al, 2006, Penelitian Hukum Normatif suatu Tinjauan Singkat, Rajawali, Jakarta.

Soemitro, Ronny Hanitijo, 1990, Metodelogi Penelitian Hukum dan Jurimetri, Ghalia Indonesia, Jakarta.

Sudjito, 2014, Ilmu Hukum Holistik : Studi Untuk Memahami Kompleksitas dan Pengaturan Pengelolaan Irigasi, Gadjah Mada University Press, Yogyakarta.

Sumadi, 1988, Metode Penelitian, Rajawali, Jakarta.

\section{B. Artikel Jurnal}

Christiani, Theresia Anita, "Studi Hukum Berdasarkan Perkembangan Paradigma Pemikiran Hukum Menuju Metode Holistik", Jurnal Hukum Pro Justitia, Vol. 26 No. 4, Oktober 2008.

Dwisvimiar, Inge, "Keadilan dalam Perspektif Filsafat Ilmu Hukum", Jurnal Dinamika Hukum, Vol 11, No. 3, September, 2011.

Nasution, Bahder Johan, "Kajian Filosofis Tentang Konsep Keadilan dari Pemikiran Klasik Sampai Pemikiran Modern", Jurnal Yustisia, Vol. 3, No. 2, Mei - Agustus, 2014.
Samekto, FX. Adji, "Menggugat Relasi Filasat Positivisme Dengan Ajaran Hukum Doktrinal", Jurnal Dinamika Hukum, Vol. 12, No. 1, Januari, 2012.

Swantoro, Herri, et. all, "Permohonan Upaya Hukum Peninjauan Kembali Kedua Kali Berbasis Keadilan dan Kepastian Hukum", Mimbar Hukum, Vol. 29, No. 2, Juni, 2017.

\section{Internet}

BBC Indonesia, "Pelarangan ojek online: Presiden panggil Menhub", http:// www.bbc.com/indonesia/berita indonesia/2015/12/151218_indonesia_ presidenmenhub, diakses 11 November 2017.

Harian Rakyat Merdeka, "YLKI Dibanjiri Keluhan Kinerja Taksi Online”, http://ekbis.rmol.co/ read/2017/08/03/301482/YLKI-DibanjiriKeluhan-Kinerja-Taksi-Online-, diakses 26 Desember 2017.

Pengembang KBBI Daring, "Kamus Besar Bahasa Indonesia", https://kbbi.kemdikbud.go.id/ entri/aman.

Pambudi, Joko, "Pengemudi Rampok Penumpang, Polisi Akan Panggil Manajemen Taksi Online", http://www.pikiran-rakyat.com/ bandung-raya/2018/01/19/pengemudirampok-penumpang-polisi-akan-panggilmanajemen-taksi-online-418193, diakses 19 Januari 2018.

Solehudin, Mochamad "Diancam Sopir Angkot, Aher Tunggu Arahan Pusat Soal Taksi Online", https://news.detik.com/berita-jawabarat/d-3676465/diancam-sopir-angkotaher-tunggu-arahan-pusat-soal-taksi-online, diakses 11 November 2017. 
YLKI, "Pelarangan ojek online: YLKI minta angkutan umum 'diperbaiki'" https:// $w w w . b b c . c o m / i n d o n e s i a / b e r i t a$ indonesia/2015/12/151218_indonesia_ylki_ larangangojekdll, diakses 18 November 2018.

\section{Peraturan Perundang-Undangan}

Undang-Undang Nomor 8 Tahun 1999 tentang Perlindungan Konsumen (Lembaran Negara Republik Indonesia Tahun 1999 Nomor 42, Tambahan Lembaran Negara Republik Indonesia Nomor 3821).

Undang-Undang Nomor 22 Tahun 2009 tentang Lalu Lintas dan Angkutan Jalan (Lembaran Negara Republik Indonesia Tahun 2009 Nomor 96, Tambahan Lembaran Negara
Republik Indonesia Nomor 5025).

Peraturan Pemerintah Nomor 74 tahun 2014 tentang Angkutan Jalan (Lembaran Negara Republik Indonesia Tahun 2014 Nomor 260, Tambahan Lembaran Negara Republik Indonesia Nomor 5594).

Peraturan Menteri Perhubungan Nomor 108 Tahun 2017 tentang Penyelenggaraan Angkutan Orang dengan Kendaraan Bermotor Umum tidak dalam Trayek (Berita Negara Republik Indonesia Tahun 2017 Nomor 1474)

\section{E. Putusan Pengadilan}

Putusan Mahkamah Agung Nomor 15 P/HUM/2018 perihal Peninjauan Kembali Daniel Lukas Rorong, dkk Vs Menteri Perhubungan RI, 31 Mei 2018. 